\title{
TIME AND COSMOS: A ZOOMORPHIC COSMOLOGICAL MONUMENT OF THE LATE ANTIQUITY
}

\author{
Nikolay Sivkov
}

\begin{abstract}
The protome of the ram from West Bulgaria is a lunisolar calendar of parapegmatic type from the period of antiquity ( $2 \mathrm{nd}-4$ th century $\mathrm{AC}$ ), which imparts encoded calendrical, cosmological and cosmogonic information.

On the protome there are marked synodic, sidereal, and draconic months; lunar, solar and draconic years, as well as different time periods - seasons and cycles. One of the images on the protome's body can be interpreted as an image of the Draco constellation around the fixed point of the North Pole in the centre of the ecliptic. The symbols of seven luminaries - the Sun, the Moon and five planets - which were known at the beginning of the first millennium are also featured on the protome.

In the context of the monument, the presence of the astronomical concept of the world axis and the centre of the ecliptic means that the creators of the ram's protome perceived it as an omphalos, the sacred centre of the world, the zoomorphic model of the world mountain and the world tree. The suggestion is confirmed by the structural particularities of the protome, by the images of mythological characters and by scenes of cosmogonic motifs. The given artefact represents the conceptualisation of the world in a generalised, syncretised and interdisciplinary way through the language of astronomy, mythology and calendaristics.

In the period of antiquity, time and space were perceived as a united integer and as an endless divine beginning connected with the universe and its divine essence. The calendar is an attempt to comprehend the phenomenon of an infinite and cyclic time and use it in practice during the terrestrial life.
\end{abstract}

Key words: centre of the ecliptic, Draco constellation, lunisolar calendar, North Pole, protome of the ram, synodic, sidereal, and draconic months, Thrace

\section{INTRODUCTION}

Half a century ago (in 1962) in Bosnek, a small mountain village in the centre of the Balkans, just $20 \mathrm{~km}$ away from Sofia (42.4833 N, 23.1833 E), two locals dug out an extraordinary object - a clay head of a ram (Radonov 1965: 53). The head was not big - $19 \mathrm{~cm}$ high and $13 \mathrm{~cm}$ long in the base, conical in form. The body of the ram was not found, it actually did not exist. The object was a 

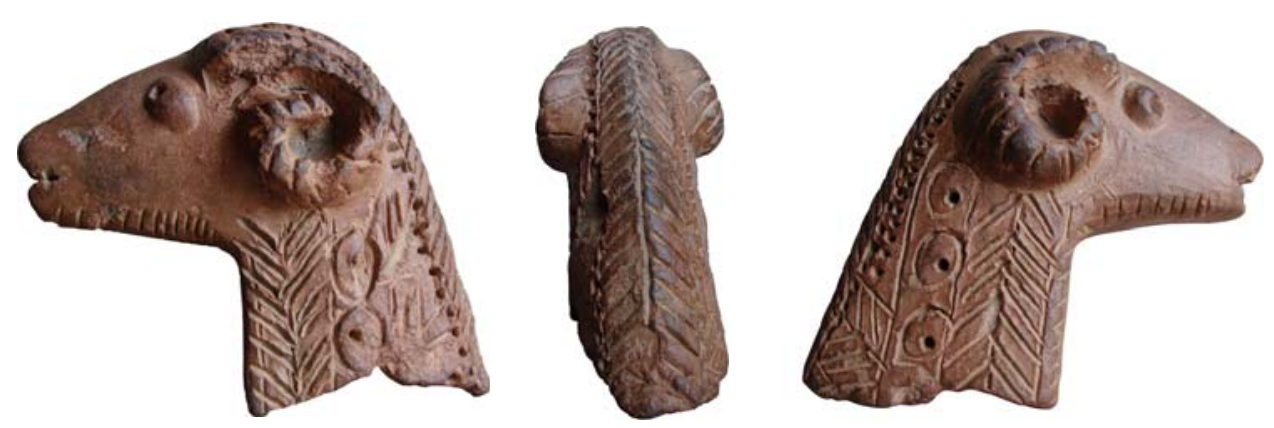

Figure 1-3. Left (1), back (2) and right (3) side of the ram. Photos from History Museum of Pernik, 2007.

protome - an object of cultic usage (Fig. 1-3). The place where it was found was most probably a site of an ancient sanctuary, on which a Christian church had been later built. Archaeologists dated the artefact to a period from the 2 nd to the 4 th century. Several other objects had been discovered in the vicinity: a bas-relief of Mithra, a figurine of a bird, and Roman and Thracian coins (MitovaDzhonova 1983: 22).

Bosnek is situated on the western side of the mountain massif Vitosha (Thracian 'Scombros') which is renowned for its caves and spring waters.

From the 2nd to the 4th century the central Balkans constituted a part of the Roman Empire (the province of Thrace). At the time, the population of this province was mostly Thracian, but in different times its land was trodden by the feet of Macedonians, Romans, Celts and Goths (Gerov 1961: 254; Danov 1969: 110-111). This is why the ethnic origins of this object remain disputable. At first researchers attributed its origin to the Celts and included it in the range of so-called 'Celtic cult figurines' (Gerasimov 1960: 188-189; Mikov 1932: 186).

Later, though, this opinion became an object of critique, as stone and clay protomes of rams and horses on the Balkan Peninsula can be found in places where there are no traces of Celtic presence, or they belong to a period preceding the Celtic invasions of the 3rd to the 1st century BC (Domaradski 1984: 146-149). Considering the place of finding, the dating and the semantic characteristics of this given object we can presume that it belongs to the relics of the Thrace culture, but at the same time we cannot exclude the possibility of its syncretic origin.

The results of the analysis showed that the protome of ram from the village of Bosnek represents an ancient lunisolar calendar of parapegmatic type. ${ }^{1}$ 


\section{THE CALENDAR}

Below follows a short description of the calendar system (Sivkov 2005: 353-359).

On the body of the protome there are numerous signs of two kinds - incisions and parapegmatic concavities (265 in total). These signs are not chaotically spread but are arranged by type in seven groups consolidated in four blocks.

First block - back of the ram: incisions, three parapegmas

Second block - sides and horns of the ram: incisions

Third block - front part of the ram: incisions

Fourth block - crown of the ram: grain prints

The three parapegmas of the first block were used as a major calendar instrument for practical purposes:

1. Parapegma A ("the Big Parapegma") runs along the back of the ram (on the left and to the right) and features 28 signs (round concavities) [16+(11+1)] (Fig. 4)

2. Parapegma B ("the Small Parapegma") runs on the sides and on the head of the ram ("eyes" and "nostrils") and features 9 signs $(2+3+4)$ (Fig. 1, Fig. 3)

3. Parapegma C ("the Lunar Parapegma") runs along the back of the ram and features $22 / 23$ signs $(15+7 / 8)$. This parapegma differs from the others as it is formed by lunar symbols rather than by oval concavities (Fig. 4).

There was probably a set of pins that were shifted from one indent to another, to count days, weeks, months and years.

The signs of Parapegma A $(16+11+1)$ as well as parts of Parapegma B $(3+2)$ allow us to count the days of both lunar and solar calendar months, consisting of 29/ $30,30 / 31$ days, respectively. The sum of the figures 29 $(27+2)$ and $30(27+3)$ gives the number of the days of two synodic months (29.53 E $2=59.06$ days). The two synodic months are also marked by incisions on the back of

Figure 4. Back and crown of the ram. A sketch illustrating Parapegma $A$ and Parapegma $C$ on the back of the ram.

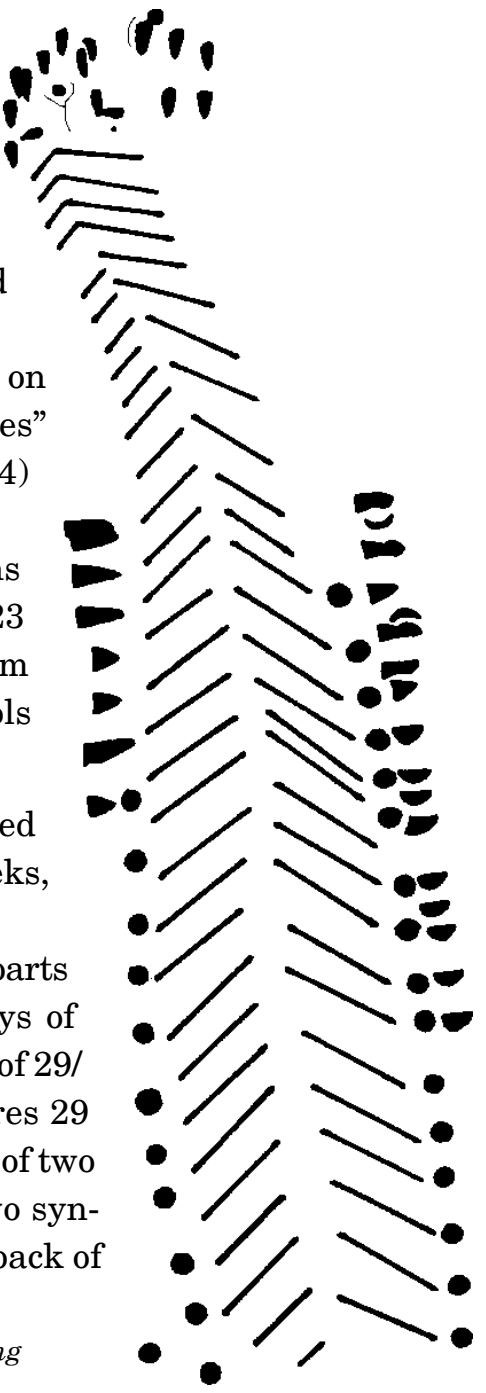


the ram $(31+28)$. Twelve synodic months equal a lunar year (354/355 days). At the same time the combination of signs $28+2=30$ and $28+3=31$ allows to figure out the solar year (365/366 days) ${ }^{2}$.

It is interesting to note that if we pass the 28 concavities (Parapegma A) twice, we get the number 56 - the Sarsen cycle of eclipses of the Stonehenge, according to which lunar and solar eclipses alternated every 56 years, with a variation of 3-5 days (Hawkings 1984: 180-182).

Parapegma C ("the Lunar Parapegma") features 22/23 signs (15+7/8). In antiquity an intercalary (additional) month was periodically included in the lunar calendar in order to adjust the span of the year. ${ }^{3}$ In this case the span of the lunar year varied between 354 and 376/377 days.

In the frontal part of the protome's body there are two separate groups of signs. In the group on the left the number of incisions corresponds to the number of the months in one year (12/13). The number of incisions on the right side (18/19) could be related to the years and interpreted as a Metonic cycle (19 years), a Saros eclipse cycle (18 years $+10 / 11$ days), or as a period of the shifting of lunar nodes along the ecliptic (18 years +222 days).

Of all these variants the most probable is the 19 year period of superposition of the solar and the lunar cycle (Seleshnikov 1985: 105), while the other two intervals were supposedly also known to the compilers of the calendar. ${ }^{4}$ The skills of priests to predict solar and lunar eclipses were based on the knowledge of the duration of the saros - the interval of 19,756 days of 24 hours, after which an eclipse will recur. Knowing the time of all the eclipses which took place within approximately 54 years, one could predict the occurrence of the following eclipses over a period of many saroses.

The incisions on the horns of the ram, combined with the incisions on its sides (representing a plant ornament), supposedly impart information about the duration of the three periods of the tropical year and the days of the cult celebrations.

In spite of the abundance of calendrical information there is no number which would reflect a full lunar (364) or a full solar (365) year. These numbers can be deduced only indirectly. However, the total number of the signs on the protome is 265, which corresponds to the number of days in the "Apollonian" part of the agricultural year (29.53 E x $9=265.77)$, according to Plutarch. ${ }^{5}$ At the same time the winter or the so-called "Dionysian" part of the year remains hidden from the observer's eyes. ${ }^{6}$ This is reflected in the absence of signs corresponding to the three winter months, as well as in the construction peculiarities of the object. An image of a wild boar which represented the winter part of the year, and was a correlate of the ram, is hidden in the bottom part of the protome. 
Chronologically, this relic is dated by archaeologists to the period between the 2 nd to 4 th centuries. In antiquity calendars were mainly used for practical (farming or cultic) purposes and instead of the whole year included information about separate periods of time related to the agricultural cycles, cattle breeding cycles, or those specific to the life of man and society, and to ritual practices (Hesiod 1982: 383-404; Varro 1963; Bickerman 1985: 23; Opperman 1984: 126).

\section{COSMOLOGY}

The fact that the concept of time in an agricultural society was defined by the cycles of nature played a major role in shaping human psyche. The thinking of Thracians, Geto-Dacians, and the Scythians was cosmological (Raevskii 1977: 62; Akishev 1984: 79). Since the very early antiquity, the calculation of time was regarded a sacred act. The cosmos as a sacred reality was related to the cosmic time ("the Year", "the Great Year") and the terrestrial calendar used for calculating the cosmic time reflected the unity of the divine origin and the earthly reality - the connection between man, nature and cosmos (Eliade 1998: 12). Its orientation was the sky and the movement of the main luminaries the Sun, the Moon, and the planets.

On the crown of the ram there is another group of 17 signs resembling grains (possibly barley) (Fig. 5.1). These are arranged in the form of the letter S, and represent a stylized image of the head of a bird (Fig. 5.2). It could be an eagle, the bird of Zeus and Apollo, or a rooster. The winded body of the bird (the V-form incisions on the back of the ram) looks like the body of a feathered snake. This is why the image resembles most probably a mythical polymorphic creature - gryphon or a bird-snake - in whom the characteristics of a bird and a reptile are combined. ${ }^{7}$

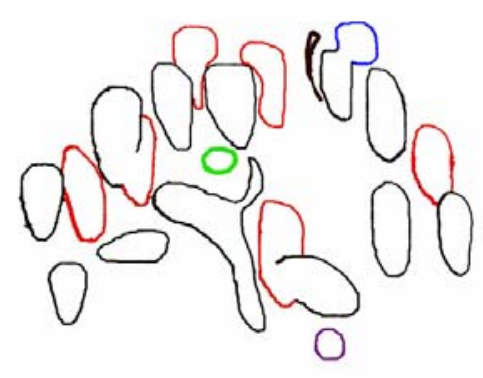

Figure 5.1. Crown of the ram. Outline of 17 signs resembling grains situated on crown of the ram.

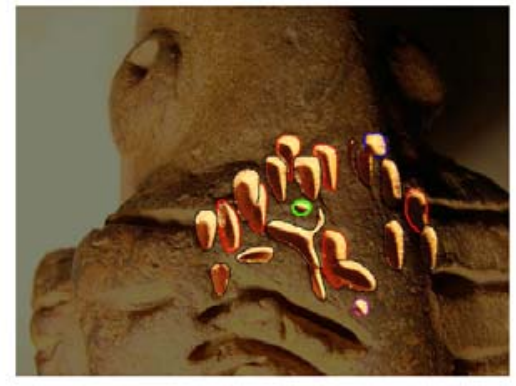

Figure 5.2. Crown of the ram. Photo from History Museum of Pernik, 2007. 


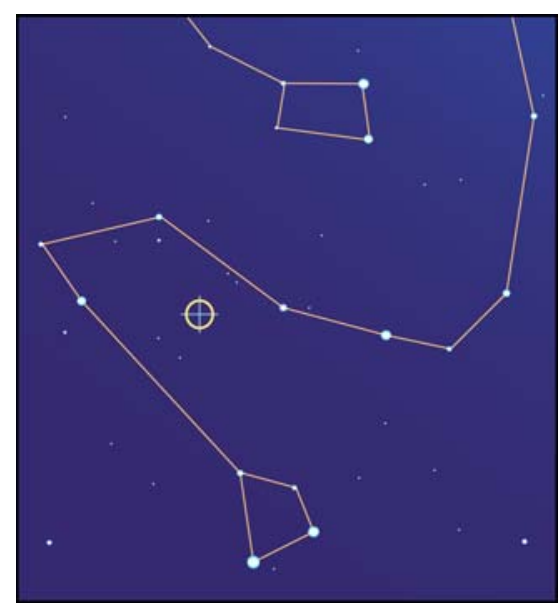

Figure 6. Ursa Minor and Draco constellations.

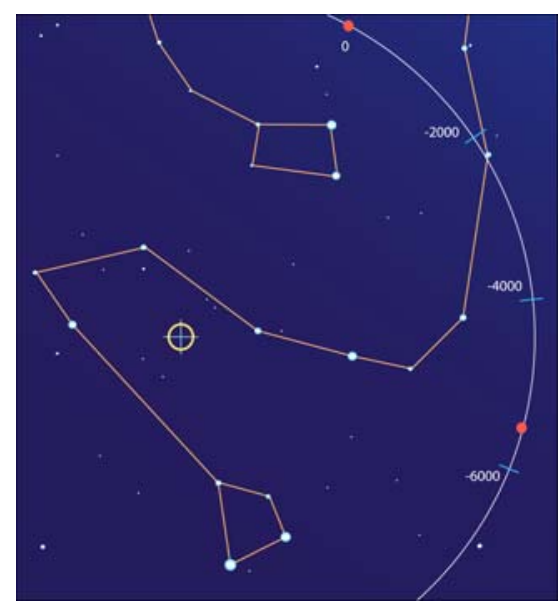

Figure 7. Ursa Minor, Draco constellation and the World Pole during the last few milleniums.
The configuration and the number of signs in this group are identical to the configuration and the number of major stars in the Draco constellation (Fig. 6). The sole difference is in the last two "stars" in the front part of the image. It is possible that they belong to another constellation - Ursa Minor (stars Beta and Gamma). The eye of the gryphon corresponds to the location of the point of the North Pole of the ecliptic in the Draco constellation. ${ }^{8}$ At the beginning of the 1st millennium, the World Pole was also situated close to the Beta star of the Ursa Minor (Fig. 7). It might be that this is exactly what is marked, in the form of a concavity, above the last (next to last) sign in this group (Fig. 8).

This situation clarifies the presence of "the Sun" and "the Moon" (the eyes of the ram) ${ }^{\mathbf{9}}$, as well as the five planets (Mercury, Venus, Mars, Jupiter, and Saturn), known already to Plutarch, located, in the form of bird heads, on both sides of the protome around the parapegmatic concavities of the small Parapegma B $(2+2+3) .{ }^{10}$ Visually, the trajectory of planet movement passes close to the ecliptic, therefore their position around the pole of the ecliptic is totally reasonable.

These astronomic objects did not find their place on the body of the protome by mere chance.

Although 2000 years ago the point of the Vernal Equinox shifted from the Aries constellation to that of Pisces, the constellation of the Ram has remained to be the beginning of the year in calendars of antiquity (Ovid: X 165), including the calendar of Thracians, and thus the Ram represented the Alpha and the Omega of both cosmic and terrestrial years. 


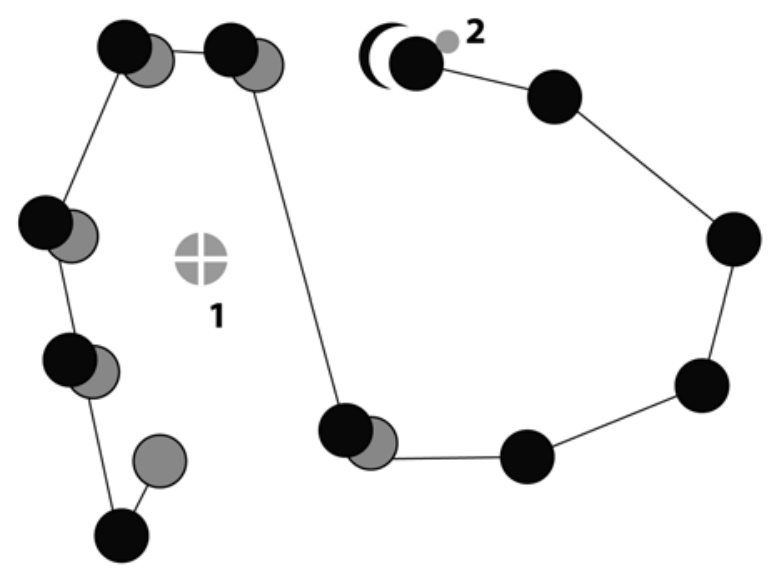

Figure 8. The North Pole of the ecliptic in the constellation of Draco on the protome of the Ram. 1 - North Pole of the ecliptic; 2 - Centre of the World, 2-4 c AC

\section{COSMOGONY}

Provided our supposition is true, it would mean that the protome depicts the two major axes of the Universe (Morozov 1997-2003: Introduction), and the protome itself represents the Centre of the Universe, the sacred Omphalos of the inhabitants living in this part of the Balkan Peninsula two thousand years ago. ${ }^{11}$ The artefact has the form of a regular cone, reminiscent of an omphalos or a reduced model of a mountain - the World Mountain.

On the sides of the protome a complex plant ornament is illustrated in the form of two "trees". Their branches point in different directions: down - on the right side, and up - on the left. This creates an ambiguous impression as we have either two separate trees growing in different directions, in a vertical layout, or one tree with its branches up and roots down (Zehren 1976: 122). In both situations this plant is associated with the ancient cosmogonic image of the World Tree and is reminiscent thereof.

As is generally known, the vertical aspect of the World Tree is divided into three zones. The upper one is inhabited by birds, the middle one - by hoofed and horned animals, and the lowest - by carnivorous animals and reptiles.

In this case, there are all the elements present, regarding the construction of the World Model, yet its three-part structure is reduced to a two-part one. The ram represents the middle zone, the upper and lower ones being epitomized by the gryphon - the bird-reptile which is a zoomorphic incarnation of both of the worlds beyond, similarly to the bird-lion gryphon in Greek-Scythian art (Raevskii 1985:150). A correlation like this, picturing a gryphon, in the 
form of carnivorous bird with a snake body, was typical of Thracians, as well as of Geto-Dacians, tribes related to the Thracians (Tsiv'ian 1984: 47; Nikulitse 1987: 129, 154-155; Marazov 1992b: 12, 29).

The scene "tearing to pieces", which often accompanies the picture of the World Tree, is also present. ${ }^{12}$ This is seen in the mutually relative placement of the gryphon and the ram. The stylized gryphon, positioned on the back of the ram, resembles an attacking predator. The semantics of "sacrifice" of this composition is indirectly substantiated by the image of a horned animal (a ram?), depicted in the bottom part of the protome, conditionally captured in the gryphon's claws. ${ }^{13}$

This archaeological artefact could thus be interpreted as the World Mountain, the World Tree, or their zoomorphic invariant (Evsiukov1988a: 75). The threefold cosmic structure of the World Centre is encoded in this in three different aspects - spatial, zoomorphic, and narrative (Marazov 1992a: 10).

Cosmogony includes equally the creation of the world, as well as the creation of time. The cyclic revival of the world is taking place together with the cyclic revival of time. Moreover, the cosmic time generated in cosmogony comes as a model for any other form of time, as cosmogony itself is the archetype of any "creation". The existence of the carrier of the archetypal model of the world is mythologized. Getting into that world, as if in a sacred text, real objects are automatically mythologized (level of primary mythologization) (Tsiv'ian 1984: 50-51). This phenomenon is, to a great extent also referable to the calendars of the period of antiquity.

Time is as real and material as the rest of the world. It can be put in order and divided - that is what the gods were engaged in when creating the world. This is why in calculating calendrical time, the astronomic and the mythological aspects are mutually closely interrelated and reciprocally complement the integral picture of the world. The same information, on the ram protome from Bosnek, is often repeated through different means of expression. The astronomical and mythological interpretation of the World Centre is just an example of that.

For instance, the total number of calendar signs (265) corresponds to the nine lunar synodic months - the "Apollonian" part of the year (calendar aspect), revealing that this calendar is agricultural and its main content includes the part of the year related to fertility and harvest-time. From the point of view of cosmology, however, the same text could be regarded in a different way. On the crown of the ram the eye of the gryphon is set in the fork of the letter Y. Bearing in mind the degree of stylization of the picture on the whole, we can compare upsilon with the symbolic image of the Milky Way with its fork in the Cygnus constellation, as can be seen in the night sky for nine months in the 
year, from March to November. Though, it does not mean that this is the only possible interpretation of the sign.

Indeed, there is also the third possible aspect - the cosmogonical one. On the protome the head of the 'eagle' is located in the highest possible position, and is made from grain seeds (barley?), which corresponds to the positioning of the summer solstice. The eagle was regarded as a bird of both the solar deity Apollo and Zeus, the god of thunder. On the opposite side, in the bottom part of the protome, as already mentioned, there is a hidden chthonic animal - the wild boar, exterminator of the cereal crops, marking the winter - 'Dionysian' part of the year and respectively the position of the winter solstice (Marazov 1992b: 349).

In this way the zones of chaos and cosmos become localized in the structure of the World Axis, opposed to each other as "upper and lower", "visible and invisible", "solar and chthonic" and at the same time representing a whole cosmogonic entity, cyclically transforming from one into the other through the act of "death and resurrection".

Another example of the multi-dimensionality of the non-verbal sacral text is the role and the place, within the model of the world, of the very ram itself, represented by the protome.

The correlation of the summer solstice (or the "Apollonian" part of the year) with the winter solstice (or the "Dionysian" part of the year) is balanced by the presence of the ram as a symbol of the vernal and autumnal equinox, the beginning and the end of the agricultural year (calendar plan).

Being the zodiacal constellation, which two thousand years ago was the astronomical point of the intersection of the ecliptic and the celestial equator, the Aries marks the period of creation of the artefact, as well as the culture and the worldview of the society of that time (cosmological aspect).

In ancient mythology the ram usually assumes the role of a mediator, travelling in the World Tree and carrying out the contact between men and the world beyond (Chevalier 1996: 111-112). In this hypostasis, in the ideas of Thracians and Greeks, the ram was present as the mount of the deity Hermes a deity-mediator between men and heavenly beings, taking the souls of the deceased to the world beyond. ${ }^{14}$ In the given case, the image of the ram is not confined to the role of the cosmic contactor, though it is present. The ram is a zoomorphic variant of the world model itself and of its centre. ${ }^{15}$ The presenting of this model simply in the form of a head, without the rest of the body (pars pro toto), is explained by the fact that in ancient society, the symbol of a dismembered head of an animal did not only have a phallic meaning (Onians 1989: 232), but also stood for "sacrifice" which is again associated in context with the periodical death and resurrection of the cosmos, and with the sea- 
sonal renewal of nature (Marazov 1992b: 372; Frazer 1980: 477-484; Tsiv'ian 1989: 119) (cosmogonic aspect).

The ram is still revered by the Balkan peoples as a sacrificial animal in wedding and funeral rituals, i.e. in the rituals representing transition from one social status into another and from one world to another (Marazov 1992b: 117-119). The cult of ram is related with the winter Christmas and spring rituals, which are the borders between the calendar cycles. Survakars - disguised participants of the rural winter carnival in Western Bulgaria put on ram skins and masks every year in the night between the 13th and 14th of January. Ram meat serves as sacrifice for the day of St. George - 23rd of April according to the Julian calendar. ${ }^{16}$ This Christian festival of shepherds and farmers has deeply hidden pagan traits. The folk calendar relates the day of St. George to the beginning of spring and awakening of nature. In antiquity it was conceived as hierogamy (sacred marriage), which was also invariably accompanied by the sacrifice of a ram (Marazov 1992b: 183-185).

Within the Bulgarian folklore tradition, the Christian image of St. George as a "wolf shepherd" (Losev 1957: 282) has preserved the mediatory and the shaman functions of ancient Hermes. Thus, having lost the meaning of a "world centre", the ram still retains in society the role of a mediator between space and time. ${ }^{17}$

Finally, let us try to answer one question: what is the direction towards which the ram from Bosnek is looking? At first sight there seems to be no answer to this question yet astronomy could help us in seeking one.

In Bulgarian folklore songs we can find St. George, at times, described as a guide of the souls of the deceased to the world beyond, similarly to Hermes and his ram.

Archaeologists have discovered that in ancient burials containing the remnants of rams, the animals were "looking" to the West - towards the land of the deceased (Nesterov 1990: 83; Smirnov 1964: 215-216).

The position of the Draco constellation, located on the East - West axis on the crown of the ram, points towards the period of the year when, at sunset, the Aries constellation also sets in the west, - i.e. the first ten days of May, the time of celebrating St. George's Day according to the Gregorian calendar. On this day the mythical ram of Hermes is leaving for the land of ancestors, to the world beyond. He will be coming back from there at the end of September beginning of October. The heads of rams, placed on top of stakes on the burial mounds of the Vlachs - ancestors of Romanians, also "look" in the same direction. ${ }^{18}$ The circle closed.

In cosmogony, the Ram is simultaneously a symbol of an end and of a new beginning in the life of the Universe. The end of the world (aeon in Greek), 
according to the ideas of archaic man, comes in the end of every calendar cycle, because for him time is not linear and profane, but cyclic and doctrinal (Fol 1998: 93, 129; Eliade 1995: 29-30).

The time of the Ram is the time of "eternal return", resurrection through death.

To the calendar cycle we have to add also the precession cycle. In this sense the Ram, much like the god Janus, stands at the border not only between two worlds, and two parts of the year, but also between two eras.

During the era of the naissance of Christianity the Ram became one of the first symbols of the future world religion, ${ }^{19}$ and by the time the precession pushed it aside it had to give its place as a cosmic pillar and an omphalos to the Pisces.

\section{NOTES}

1 'Parapegma' (from Greek parapegma - 'list', 'records', 'calendar') is a stone plate with holes in which pins were inserted to mark the dates of the current month. In Greece a similar parapegma was set up in the centre of Athens in $432 \mathrm{BC}$ (Seleshnikov 1985: 111).

212 months of 28 days could separately constitute a lunar year of 336 days with an addition of a 13th intercalary month of 30 days. Such calendars have been known in the agrarian cultures of Middle Asia since the Neolithic era (Levin 1982: 33-34).

${ }^{3}$ In the ancient Roman calendar from the times of Numa Pompilius (7th century BC), for instance, the additional month (Mercedonius) was that of 22 or 23 days (Seleshnikov 1985: 57).

4 A 222 days' interval can be estimated by means of the Big and the Small Parapegmas: $(28+9) \times 6=222$.

5 The total number of signs on the protome (265) corresponds to the nine months of the lunar year (29.53 x $9=265.77$ ), which Plutarch refers to as the "Apollonian" part of the year. The other part of the lunar year, called "Dionysian" (the remaining three months), remains hidden (Plutarch 1978: 245).

${ }^{6}$ In this context the calendar from Bosnek is not unprecedented. In the famous calendar of Romulus (8th century BC) only 10 of the total of 12 months (304 days) are mentioned.

7 The name 'gryphon' or 'griffin' for this kind of creature is conditional. The image comes from Greek mythology. Classical images of Greek gryphon represent fantastical polymorphous creatures with the body of a feline predator, wings, head of a bird of prey with ears, often crowned with horns (Zamarovsky 1994: 118; Smirnov 1964: 215261). Cf., the eagle-gryphon on a bronze application from Gradeshnitsa (Nikolov 1987: 74). The images of a bird of prey with a serpent body are depicted on the left 
and right edge of a leg-plate from a Thracian tomb in Adzhigiola, Romania (Nikulitse 1987: 154-155). Serpents with bird heads, on the left side of a golden helmet from Băiceni, Romania, are situated vertically, with an image of a ram head in-between them (Nikulitse 1987: 129). Applications with the image of a bird-serpent are also present in Scythian art: the Khomina Mogila burial, 4th century BC (Opperman 1984: 126); the horned eagle gryphons of the Amu-Darya treasure, 4th to 2nd century BC (Rudenko 1949: 24).

8 The pole of the ecliptic is subject to the phenomenon of precession - the shifting of the point of vernal equinox along the ecliptic (Pakhomov 2001). In the 2 nd century BC, the phenomenon regarding the precession of the equinoxes was discovered by the Greek astronomer Hipparchus (190-125 BC), however, some researchers are of the opinion that the precession was known long before him. According to Georgio de Santillana and Gert von Dechend (Hamlet's Mill, 1969) the ancient knowledge about this astronomical phenomenon finds its proof in the folklore of many peoples of the world. They presume that mythological images should be regarded as elements of the system of ancient scientific knowledge. This knowledge primarily relates to precession of the equinox, change of eras, and disastrous events which conclude the full cycle of the precession (Santillana \& Dechend 1977). The hypothesis put forward by Santillana and von Dechend became a subject of harsh criticism. One of the few serious scientists who decided to check it was the archeo-astronomer Jane B. Sellers (Sellers 1992).

9 The left eye (semi-closed) probably represents the Moon, and the right one (open) the Sun. This supposition is substantiated by multiple examples from the world folklore. E.g., in ancient Egyptian amulets the images of the right and the left eye represented the Sun and the Moon - the eyes of the god Amon-Ra, a deity whose sacred animal was the ram (Shakhnovich 1971: 130; Frazer 1980: 469; Hornung 1971: 146).

${ }^{10}$ We can see a similar picture in the Egyptian art. According to G. V. Nosovskii and A. T. Fomenko, the planets on the zodiac of Athribis are presented as birds. "In the Lower Athribis zodiac, there are 5 birds in the zone of the Gemini constellation: 2 on one side of the man with the raised hand, and 3 on the other. The man with the raised hand on Egyptian zodiacs symbolizes the summer solstice. In this particular case there are two planets on one side of the Sun, and 3 - on the other." (Nosovskii \& Fomenko 2002: 22, 166-167)

${ }^{11}$ René Guénon defines the omphalos ("the hub of the universe") as one of the symbols of the "Centre of the World" in ancient traditions, yet the symbol of the omphalos could also be located in a place which served as a centre for a certain region.

${ }^{12}$ Cf., an eagle gryphon attacks a reindeer - Letnitsa treasure (Opperman 1984: 142). A composition representing an animal confrontation in Scythian art: an eagle gryphon attacks a mountain ram - Pazarykskii barrow (Rudenko 1949: 55); a moose in the claws of an eagle - Amu-Darya treasure (Rudenko 1949: 24); a gryphon pecking the head of a reindeer - Chertomlyk barrow (Alekseev 1991: 12).

${ }^{13}$ Cf., on the silver goblet from Rogozen (4th-2nd centuries BC), North Bulgaria, a horned bird is carrying a hare in its claws and a fish in its beak (Nikolov 1986: 38); the same scene we find on the helmet from Peretu, Romania (Nikulitse 1987: 129); on the silver goblet from Adzhigiol, a similar bird is carrying a ram (Mongait 1974: 318). In other cultures: on a pendant belonging to Sarmatian culture a bird of prey is 
holding a goat in its claws (Zavitukhina 1977: 69); we find an eagle carrying a gazelle on objects from the Sassanid period (Bongard-Levin 1989: 160-161); in a Buryat shaman legend an eagle is carrying away a sheep (Eliade 1951: 69).

14 The fact that this animal pertains to Hermes or is directly related to him is supported by the caducei - Hermes's attribute which is pictured on the left side of the protome. E.g., on the votive bronze hand from the village of Gradnitsa, Central Bulgaria, we find images of a ram and caduceus (Hermes's attribute) next to each other (Milchev 1977: 64). About the mediating function of the World Tree itself, see Evsiukov 1988b: 53 .

${ }^{15}$ Cf., zoomorphization of the World Tree in the Thracian culture, where it is represented by a horse (Fol: 1986: 145).

${ }^{16}$ On St. George's Day in Eastern Serbia, the herd is let outside early in the morning led by the oldest ram with a candle lit on its right horn. Thereafter, the candle is kept hidden and used for curing ill sheep (Koleva 1981: 56). In a Bulgarian tale, the brothers of St. George throw him into a well, at the bottom of which there live two rams - one white and one black. The black one carries him to the "black world" where he saves the offspring of a bird from a snake. As a reward the bird takes him to the "white world" (SNU 1889: 118-120).

${ }^{17}$ E.g., the riddle about the Sun from the region of Bosilegrad, Eastern Serbia: "They slaughtered a ram on the lower mountain, and its blood spilled down on the higher mountain". ("The voice of Bulgaria in Serbia", year 1, No. 1, 22.10.1995, p. 29)

18 The Vlachs (Volokhs, Walachians) are ancestors of the Romanians and descendants of the Geto-Dacians (Potebnia 1865).

19 The ram is a sacrificial animal in the Bible (Ex. 29:15-16; 29:18; Lev. 8:18; 8:20-22; 9:2; 9:4; 14:13; II Chron. 29:22; 29:32). In Christian iconography Christ is sometimes pictured as a sacrificial lamb. The image of Christ with a ram or a lamb on his shoulders is based on the idea of the ancient Greek god Hermes as a protector of the herd (Prieur 1993: 20-22; Cooper 1993: 143). The cosmological image of transmission from one aeon to another is doubled again by the cosmogonic reminiscence of the "first sacrifice", yet, as marked by T. Tsiv'ian, "according to the scheme of the major myth, the first sacrifice was aimed at preserving the cosmic harmony of the world, and thus acquired an out-of-time universal character" (Tsiv'ian 1989: 129).

\section{REFERENCES}

Akishev, Alisher 1984. Iskustvo i mifologia sakov. [Art and Mythology of the Sakha.] Alma-Ata: Nauka.

Alekseev, Andrei \& Murzin, Viacheslav \& Rolle, Renate 1991. Chertomlyk (skifskii tsarskii kurgan IV v. do n.e.). [Chertomlyk (Scythian Tsarist Barrow of the 4th c. BC] Kiev: Naukova dumka.

Bickerman, Elias Joseph (= Bikerman, Elias Joseph) 1975. Khronologiia drevnego mira: Blizhnii Vostok $i$ antichnost'. [Chronology of the Ancient World: Antiquity of the Near East.] Moscow: Nauka. 
Bongard-Levin, Grigorii (ed.) 1989. Dreunie tsivilizatsii. [Ancient Civilizations.] Moscow: Mysl'.

Danov, Khristo 1969. Drevna Trakiia. [Ancient Thrace.] Sofia: Nauka i izkustvo.

Domaradski, Mechislav 1984. Keltite na Balkanskiia poluostrov: IV-I v. pr.n.e. Sofia: Nauka i izkustvo.

Chevalier, Jean \& Gheerbrant, Alain (=Shevalie, Zhan \& Geerbrant, Alen) 1996. Rechnik na simvolite 1-2. [Dictionary of Symbols 1-2.] Sofia: Petrikov.

Cooper, Jean C. (=Kup"r, Dzhan. K) 1993. Iliustrovana Entsiklopediia na traditsionnite simvoli. [An Illustrated Encyclopaedia of Traditional Symbols.] Sofia: Pet"r Beron.

Eliade, Mircea 1951. La chamanisme et les techniques archaïques de l'extase = Shamanism: Archaic Techniques of Ecstasy. Paris: Payot.

Eliade, Mircha (= Eliade, Mircea) 1995. Aspekty mifa. [Aspects of Myths.] Moscow: Invest-PPP.

Eliade, Mircha (= Eliade, Mircea) 1998. Mif o vechnom vozvrashchenii. [The Myth of Eternal Return.] Mif, religiia, kul'tura. Sankt-Peterburg: Aleteiia.

Evsiukov, Valerii 1988a. Mify o vselennoi. [Myths about the Universe.] Novosibirsk: Nauka.

Evsiukov, Valerii 1988b. Mifologiia kitaiskogo neolita po materialam rospisei na keramike kul'tury Ianshao. [Mythology of the Neolithic Period in China, Yangshao Painted Pottery.] Novosibirsk: Nauka.

Fol, Aleksand"r 1986. Trakiiskiiat orfiz"m. Sofia: Universitetsko izdatelstvo Sv. Kl. Okhridski.

Fol, Aleksand"r et al. 1988. Chovek"t v"v vidove vreme. Sofia: Universitetsko izdatelstvo Sv. Kl. Okhridski.

Frazer, James George (=Frezer, Dzheims Dzhordzh) 1980. Zolotaia vetv'. [The Golden Bough.] Moskva: Politizdat.

Gerasimov, Todor 1960. Keltski kultovi figuri ot B”lgariia. Izvestiia na Arkheologicheskiia institut (IAI) 23. Sofia: BAN, pp. 165-204.

Gerov, Boris 1961. Prouchvaniia v"rkhu zapadnotrakiiskite zemi prez rimsko vreme = Untersuchungen über die westthrakischen Länder in römischer Zeit I. Godishnik na Sofiiskiia universitet, filologicheski fakultet (1959-1960) 54: 3. Sofia: Nauka i izkustvo, pp. 155-406.

Guénon, René (=Genon, Rene) 1993. Tsar' mira: Predstavleniia ob Agartkhe na Zapade. [King of the World. The Concept of Agartha in the West.] Voprosy filosofii 3, pp. 97-133.

Hawkins, Gerald S. \& White, John B. (=Khokins Dzheral'd \& Uait, Dzhon) 1984. Razgadka tainy Stounkhendzha. [Stonehenge Decoded.] Moscow: Mir.

Hesiod 1982. Works and Days. Hesiod. The Homeric Hymns: And Homerica. The Loeb classical library 57. Cambridge (Massachusetts): Harvard University Press \& London: Heinemann.

Hornung, Erik 1971. Der Eine und die Vielen: Ägyptische Gottesvorstellungen. Darmstadt: Wissenschaftliche Buchgesellschaft.

Khazanov, Anatolii 1975. Zoloto skifov. [The Gold of the Scythians.] Moscow: Sovetskii khudozhnik. 
Koleva, Tatiana 1981. Gerg'ovden u iuzhnite slaviani. Sofia: BAN.

Levin, Valdimir 1982. Svideteli iz Kapovoi peshchery. [Witnesses from the Shul'ganTash Cave.] Moscow: Detskaia literatura.

Losev, Aleksei 1957. Antichnaia mifologiia v ee istoricheskom razvitii. [Ancient Mythology in Historical Development.] Moscow: Uchpedgiz.

Marazov, Ivan 1992a. Vidimiiat mit: Izkustvo i mitologiia. Sofia: Khristo Botev.

Marazov, Ivan 1992b. Mit, ritual i izkustvo u trakite. Sofia: UI Sv. Kliment Okhridski.

Mikov, Vasil 1932-1933. Keltski nakhodki u nas. B"lgarska istoricheska biblioteka V: 1. Sofia: Sofiia-pres.

Milchev, Atanas 1977. O kul'te Sabaziia v Nizhnei Mezii i Frakii. Vestnik drevnei istorii 2 , pp. 58-76.

Mitova-Dzhonova, Dimitrina 1983. Arkheologicheski pametnitsi ot Pernishki okr"g. Sofia: DI Septemvri.

Mongait, Aleksandr 1973. Arkheologiia Zapadnoi Evropy: Bronzovyi i zheleznyi vek. [Archaeology in Western Europe: the Bronze and Iron Age.]Moscow: Nauka.

Morozov, Nikolai 1997-2003. Khristos. [Christ.] Moscow: Kraft+Lean.

Nesterov, Sergei 1990. Kon'v kul'takh tiurkoiazychnykh plemen Tsentral'noi Azii v epokhu srednevekov'ia. [Horse in the Cult of Medieval Turkic Tribes in Central Asia.] Novosibirsk: Nauka.

Nikolov, Bogdan 1984. Krivodol: Drevni kulturi. Sofiia: DI Septemvri.

Nikolov, Bogdan 1986. Chashite ot Rogozenskoto s"krovishche. Izkustvo 6, pp. 37-40. Nikulitse, Ivan 1987. Severnye frakiitsy v 6-1 vv. do n. e. Kishinev: Shtilitsa.

Nosovskii, Gleb \& Fomenko, Anatolii 2002. Novaia Khronologiia Egipta: Astronomicheskoe datirovanie pamiatnikov Drevnego Egipta: Issledovaniia 2000-2002 godov. [The New Egyptian Chronology: Astronomic Dating of the Monuments of Ancient Egypt: Research 2000-2002.] Moscow: Veche.

Onians, Richard Broxton 1989. The Origins of European Thought about the Body, the Mind, the Soul, the World, Time, and Fate: New Interpretations of Greek, Roman and Kindred Evidence also of Some Basic Jewish and Christian Beliefs. Cambridge \& New York: Cambridge University Press.

Opperman, Manfred 1984. Thraker zwischen Karpatenbogen und Ägäis. Leipzig: Urania. Ovid(ius) Naso, Publius (=Ovidii Nazon, Publii) 1977. Metamorfozy. [Metamorphoses.] Biblioteka antichnoi literatury. Moscow: Khudozhestvennaia literatura.

Pakhomov, Vladimir 2001. The Mystery of the Calendar - The Message to the Unborn. Perth (Australia): Xerostar Holdings.

Plutarch (=Plutarkh) 1978. Moralii: Ob "E”v Del'fakh. [Morals.] Vestnik dreunei istorii, Vol. 1, pp. 235-252.

Potebnia, Aleksandr 1865. O mificheskom znachenii nekotorykh obriadov i poverii. [Mythological Meaning of Certain Rituals and Beliefs.] Chteniia v imperatorskom obshchestve istorii i drevnostei rossiiskikh pri Moskovskom universitete 1865 goda 2-3. Moscow.

Prieur, Jean (=Prior, Zhan) 1993. Universalnite simvoli. [Les symboles universels.] Sofiia: Gutoranov i sin.

Radonov, Zdravko 1965. Kultovi pametnitsi v okr"zhniia muzei v Pernik. Arkheologiia VII: 4, pp. 47-53. 
Raevskii, Dmitrii 1977. Ocherki ideologii skifo-sakskikh plemen: Opyt rekonstruktsii skifskoi mifologii. [Ideology of the Scythian-Saxon Tribes: an Attempt to Reconstruct Scythian Mythology.] Moscow: Nauka.

Raevskii, Dmitrii 1985. Model' mira skifskoi kul'tury: Problemy mirovozzreniia iranoiazychnykh narodov evraziiskikh stepei I tysiacheletiia do n.e. [The World Model in Scythian Culture: Worldview related Issues among the Iranian Peoples Living in European Steppes in the 1st Millennium B.C.] Moscow: Nauka.

Rudenko, Sergei \& Rudenko, Nina 1949. Iskusstvo skifov Altaia. [Scythian Art.] Moscow: Gos. muzeia izobrazit, isk. im. A. S. Pushkina (GMII).

Santillana, Giorgio de \& Dechend, Hertha von 1977. Hamlet's Mill: an Essay on Myth and the Frame of Time. Boston: Godine.

Seleshnikov, Semen 1985. Istoriia kalendaria i khronologiia. [History of the Calendar and Chronology.] Moscow: Nauka.

Sellers, Jane B. 1992. The Death of Gods in Ancient Egypt: An Essay on Egyptian Religion and the Frame of Time. London \& New York: Penguin Books.

Shakhnovich, Mikhail 1971. Pervobytnaia mifologiia i filosofiia. [Primordial Mythology and Philosophy.] Leningrad: Nauka.

Sivkov, Nikolai 2005. A Thracian Lunisolar Calendar. Aerospace Research in Bulgaria 20, pp. 353-359.

Smirnov, Konstantin 1964. Savromaty: Ranniaia istoriia i kul'tura sarmatov. [Sauromatae: The Early History and Culture of the Sarmatians.] Moscow: Nauka.

SNU 1889 = Shishmanov, Ivan et al. (eds.) Sbornik za narodni umotvoreniia, nauka, i knizhnina (SbNUNK). Sofia: Ministerstvo na narodnoto prosveshchenie.

Tsiv'ian, Tat'iana 1989. Obraz i smysl zhertvy v antichnoi traditsii (v kontekste osnovnogo mifa).[The Image and Idea of Sacrifice in Ancient Tradition.] Neroznak, Vladimir (ed.). Paleobalkanistika i antichnost': Sbornik nauchnykh trudov. Moscow: Nauka.

Tsiv'ian Tat'iana 1984. Zmeia-Ptitsa: K istolkovaniiu tozhdestva. [Snake-Bird: Interpreting the Identity.] In: B. Putilov et al. (eds.) Fol'klor i etnografiia: U etnograficheskikh istokov fol'klornykh siuzhetov i obrazov: Sbornik statei. Leningrad: Nauka, pp. 47-56.

Varro, Marcus Terentius (=Varron Mark Terentsii) 1963. Sel'skoe khoziaistvo. [Res rusticae.] Moscow \& Leningrad: Izdatelstvo AN SSSR.

Zamarovsky, Vojtech (=Zamarovskii, Voitekh) 1994. Bogi i geroi antichnykh skazanii: Slovar'. [Gods and Heroes of Ancient Sayings: Dictionary.] Moskva: Respublika.

Zavitukhina, Maria 1977. P. K voprosu o vremeni i meste formirovaniia Sibirskoi kollektsii Petra I. [About the Time and Place of Forming the Siberian Collection of Peter the Great.] In: G. Komelova (ed.) Kul'tura i iskusstvo Petrovskogo vremeni: Publikatsii i issledovaniia: Gos. Ermitazh. Leningrad: Avrora, pp. 63-69.

Zehren, Erich (=Tseren, Erikh) 1976. Lunnyi Bog. [The Moon God.] Moscow: Nauka. 